\title{
Mortality of leaf-cutting ants with salicylic acid
}

\section{Mortalidade de formigas-cortadeiras com ácido salicílico}

\author{
Juliana Chiquetti Fazam"; Gabriel Danilo Shimizu'; \\ Júlio Cesar de Almeida²; Amarildo Pasini*
}

\section{Highlights}

Salicylic acid with insecticidal effect on eusocial insects.

Commercial talc with insecticidal action against Atta and Acromyrmex.

Sustainable alternatives for integrated leaf-cutting ant management.

\begin{abstract}
Strategies for the control of leaf-cutting ants have mainly involved granular baits based on fipronil and sulfluramid as active ingredients, which are commonly coated with attractive citrus-based substances. Their constant use and the lack of alternatives in the market may favor the perception of these substances by ants, causing rejection for foraging and consequent difficulty in their control. In this respect, this study examined the mortality of leaf-cutting ants of the genera Atta and Acromyrmex subjected to direct application with dry powders, in laboratory conditions. As a preliminary treatment, a commercial antiseptic talc powder (C. A. P. T.) was used, followed by isolated treatments that corresponded to its components with potential insecticidal action, namely, salicylic acid, sulfur, boric acid, zinc oxide, in addition to an inert talc powder (Quimidrol ${ }^{\circledR}$ ) as the control. For each treatment, 40 (worker) ants, whose activity was reduced due to remaining in a refrigerator prior to the treatment, were placed in transparent crystal polystyrene ('Gerbox' type) and were sprinkled with a salt shaker. The ants were kept at $25 \pm 2{ }^{\circ} \mathrm{C}$, under a 12-h photophase, and cumulative mortality was recorded every $24 \mathrm{~h}$, considering dead ants as those that were unable to maintain the natural position of their body, i.e., even dying ants were considered dead when they exhibited no reaction when touched by a paintbrush. When sprinkled on ants, C. A. P. T. causes $40 \%$ mortality in both species $24 \mathrm{~h}$ after application. Subsequent studies of the components of this commercial product have found that when sprinkled on both Atta sexdens rubropilosa and Acromyrmex crassispinus, salicylic acid causes $100 \%$ mortality of workers in the first $24 \mathrm{~h}$. This result provides a new prospect of control through a low environmental-impact product, representing an alternative for control in nests in the field that can contribute to the integrated control of ants.
\end{abstract}

1 Doctoral Students in Agronomy, Universidade Estadual de Londrina, UEL, Centre of Agrarian Sciences, Londrina, PR, Brazil. E-mail: jufazam@gmail.com; shimizu@uel.br

2 M.e in Agronomy, UEL, Londrina, PR, Brazil. E-mail: julio.bras7@gmail.com

3 Prof. Dr., Department of Agronomy, UEL, Londrina, PR, Brazil. E-mail: pasini@uel.br

* Author for correspondence

Received: Sept. 09, 2020 - Approved: Apr. 20, 2021 
Key words: Atta sexdens rubropilosa. Acromyrmex crassispinus. Control of leaf-cutting ants. Management of eusocial insects.

\section{Resumo}

As estratégias de controle de formigas-cortadeiras têm sido realizadas principalmente com iscas granuladas, à base dos princípios ativos fipronil e sulfluramida, que são comumente revestidas por substâncias atrativas cítricas. O uso constante das mesmas e a falta de alternativas no mercado podem favorecer a percepção de tais substâncias pelas formigas, causando rejeição para forrageamento e consequente dificuldade do seu controle. Neste sentido, o objetivo do trabalho foi avaliar a mortalidade de formigas-cortadeiras dos gêneros Atta e Acromyrmex, submetidas a aplicação direta com pós secos, em laboratório. Como tratamento preliminar, utilizou-se: um talco antisséptico comercial e, posteriormente seus componentes, com potencial ação inseticida, isoladamente, sendo: ácido salicílico, enxofre, ácido bórico, óxido de zinco, além de um talco inerte (Quimidrol ${ }^{\circledR}$ ), como testemunha. Para cada tratamento foram utilizadas 40 formigas (operárias) acondicionadas em poliestireno cristal transparente (Tipo Gerbox), que foram polvilhadas com auxílio de um saleiro, estando com atividade reduzida, devido a permanência em geladeira, previamente ao tratamento. As formigas foram mantidas em $25 \pm 2{ }^{\circ} \mathrm{C}$, fotofase de 12 horas e a mortalidade acumulada foi observada a cada 24 horas, considerando-se formigas mortas aquelas que não conseguiam manter a posição natural do corpo, ou seja, mesmo formigas moribundas foram consideradas mortas, quando não exibiam reação, ao serem tocadas por um pincel. O talco antisséptico comercial, quando polvilhado sobre as formigas, causa mortalidade de $40 \%$, em ambas as espécies, 24 horas após as aplicações. Estudos subsequentes dos componentes do referido produto comercial detectaram que o ácido salicílico, quando polvilhado tanto para Atta sexdens rubropilosa quanto para Acromyrmex crassispinus, causa mortalidade de $100 \%$ das operárias nas primeiras 24 horas. Esse resultado abre uma nova perspectiva de controle, com produto de baixo impacto ambiental, sinalizando uma alternativa de controle em ninhos a campo, podendo contribuir para o controle integrado de formigas..

Palavras-chave: Atta sexdens rubropilosa. Acromyrmex crassispinus. Controle de formigas-cortadeiras. Manejo de insetos eussociais.

Leaf-cutting ants cause serious economic impacts due to their plant-material cutting habit, incurring direct damage to production. These insects have a complex social organization and structure, which makes their management difficult (Della Lucia, Gandra, \& Guedes, 2014), especially since they represent about $25 \%$ of all herbivores in Neotropical forest ecosystems (Swanson et al., 2019). Control of these species has been achieved predominantly with synthetic chemical insecticides, where the use of granular baits, sprays or dry powders is permitted.
In most ant baits, fipronil and sulfluramid are the active products with insecticidal action. This, however, has been increasingly questioned due to environmental impact problems, coupled with the rejection of granular baits for foraging by leaf-cutting ants. This has driven a search for control alternatives, whether by discovering new attractive substances derived from plant extracts, based on starch, or even by adding entomopathogenic fungi to the baits (Brito, 2018). 
Substances naturally produced by plants as a means of protection against pests or diseases may point to novel control prospects. This is the case of salicylic acid (SA), known as the sentinel of plants in defense against insects, which acts on various aspects of their growth and development by working as a modulator of responses to biotic and abiotic stress. In other words, it involves the induction of defense mechanisms that promote resistance, functioning as a plant hormone (Bhatla \& Lal, 2018). These defense mechanisms have been used in studies for the control of pest arthropods involving the application of SA, which also acts on the establishment of acquired systemic resistance (Gao, Zhu, Kachroo, \& Kachroo, 2015).

Other substances have also been researched for the control of leaf-cutting ants, e.g., boric acid, in an artificial diet for Atta sexdens rubropilosa Forel, which showed effects on the midgut epithelium (Sumida et al., 2010). For other pests, the use of sulfur (Rheinheimer et al., 2012) and zinc (Jameel et al., 2020) has been described.

Nonetheless, there have been no literature reports on the direct application of SA on insects, to examine their possible action by contact. In this scenario, the present study proposes to investigate the mortality of leafcutting ants subjected to direct application with dry powders, in laboratory conditions.

The tests were carried out at the Entomology Laboratory of the State University of Londrina, located in Londrina - PR, Brazil. The ants were collected from nests of Atta sexdens rubropilosa and Acromyrmex crassispinus Forel, where there was intense foraging activity.
Leaf-cutting antworkerswere collected using tweezers and stored in falcon tubes $(100 \mathrm{~mL})$. The powder-based products were weighed on a precision scale and $1.5 \mathrm{~g}(0.15 \mathrm{~g}$ of product/ant/replicate) were sprinkled evenly over the ants. These were then separated in groups of 10 and placed transparent crystal polystyrene boxes ('Gerbox' type) (12.0 × 12.0 $\mathrm{cm}$ ) lined with filter paper, which contained a small plastic lid of $5.0 \mathrm{~cm}$ in diameter with slightly moistened ( $1 \mathrm{~mL}$ of water) hydrophilic cotton.

Prior to sprinkling, the ants were kept in a refrigerator $\left( \pm 10^{\circ} \mathrm{C}\right)$ for 4 min, which partially reduced their activity, preventing escape and facilitating applications. Four replicates with ten ants each were used for each treatment. The ants were kept at $25 \pm 2{ }^{\circ} \mathrm{C}$, under a 12 -h photophase.

Bioassay 1: A. sexdens rubropilosa workers were used. Treatments were as follows: a commercial antiseptic powder talc (C. A. P. T.) (composition per 100 g: salicylic acid - $0.352 \mathrm{~g}$; sulfur - $17.602 \mathrm{~g}$; boric acid $3.0 \mathrm{~g}$; zinc oxide - $11.735 \mathrm{~g}$; starch - $23.47 \mathrm{~g}$; and talc q.s. - $100 \mathrm{~g}$ ); and a premium inert talc of structural formula (Quimidrol ${ }^{\circledR}$ ), referring to the pure talc mineral $\left(\mathrm{Mg}_{3}\left(\mathrm{Si}_{2} \mathrm{O}_{5}\right)^{2}(\mathrm{OH})^{2}\right.$, corresponding to the theoretical chemical composition of $31.7 \% \mathrm{MgO}, 63.5 \% \mathrm{SiO}_{2}$ and $4.8 \% \mathrm{H}_{2} \mathrm{O}$ ). Additionally, a control treatment, without any type of dry powder, consisting of only $2 \mathrm{~mL}$ of water, was applied on the ants with a spray bottle.

Bioassay 2: A. sexdens rubropilosa workers were used. The components of the commercial antiseptic powdered talc with potential insecticidal action were evaluated individually, namely, salicylic acid (99.5\%) AR 
(250 g, Synth $\left.{ }^{\circledR}\right) ;$ sulfur flor (very pure powder, 1000 g, Quimidrol$\left.{ }^{\circledR}\right) ;$ boric acid (99.5\%) AR (500 g, Dinâmica $\left.{ }^{\circledR}\right)$; and zinc oxide AR (500 g, Dinâmica ${ }^{\circledR}$ ). A control treatment, without any type of dry powder, consisting of only $2 \mathrm{~mL}$ of water, was also applied on the ants using a spray bottle.

The preliminary results with $A$. sexdens rubropilosa encouraged the bioassay with $A$. crassispinus ants. Bioassay 3: A. crassispinus ants were used, following the same abovedescribed collection and application methodology. Treatments were C. A .P. T.; its individual components, namely, salicylic acid (99.5\%, pure sulfur powder) AR, granular boric acid (99.5\%) AR and zinc oxide AR; Quimidrol ${ }^{\circledR}$ premium inert talc of structural formula, referring to the pure talc mineral; and a control treatment, without any type of dry powder, only $2 \mathrm{~mL}$ of water that were sprayed on the ants with a spray bottle.

Cumulative mortality was assessed every $24 \mathrm{~h}$ after application of the products, until the death of the control group in all bioassays. Dead ants were considered those that could not maintain the natural position of their body, i.e., even dying ants were considered dead when they showed no reaction upon being touched by a paintbrush.

The cumulative mortality values were subjected to analysis of normality of residuals and homogeneity of variances. Data were subjected to non-parametric analysis by the Kaplan-Meier survival test and the COX proportional-hazards model, using R software.

The application of the antiseptic powdered talc resulted in $40 \%$ mortality in 24 $\mathrm{h}$ and $100 \%$ in $72 \mathrm{~h}$ in A. sexdens rubropilosa workers, leading to a shorter average survival time in the laboratory. Mortality in the treatment with Quimidrol ${ }^{\circledR}$ was similar to the control, disproving the initial hypothesis of physical influence of the powder particles on the ants, either by abrasive action on the intersegments or by asphyxiation at the spiracles (Figure 1). It should be noted that the technical file of Quimidrol${ }^{\circledR}$ talc, hydrated magnesium silicate, describes its use in the pesticide industry due to its inert and diluting characteristic, where it is commonly used as a carrier for active ingredients. 
Strata - Control - C.A.P.T. - Quimidrol®
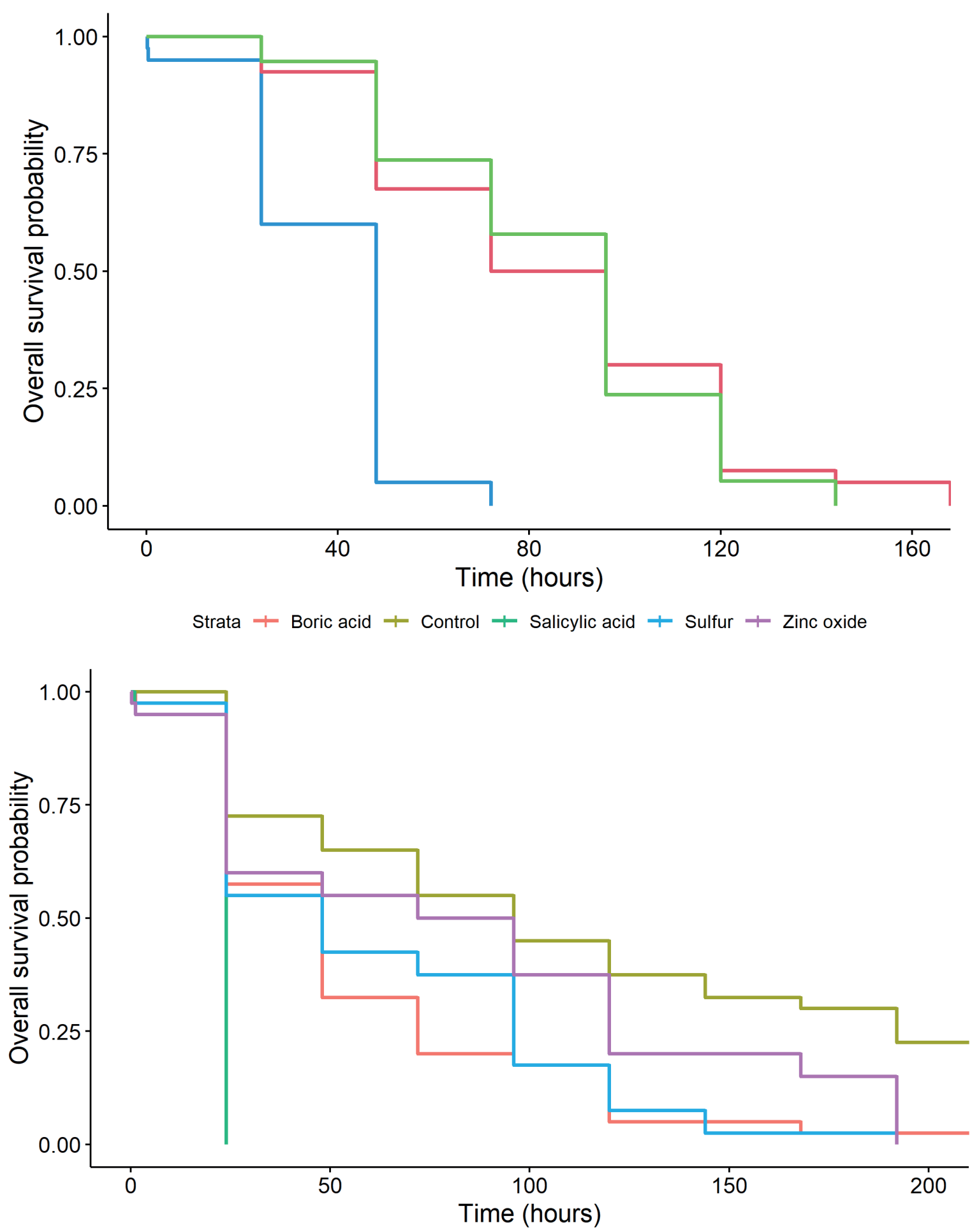

Figure 1. Survival curve, as estimated by the Kaplan-Meier method, of Atta sexdens rubropilosa workers subjected to dry-powder chemical treatments and to the chemical components of the commercial antiseptic powdered talc (C. A. P. T.) . Londrina-PR, Brazil, 2019. 
Another hypothesis is proposed whereby the insect mortality effect of C. A. $P$. T. was due to the presence of boric acid, an active ingredient already recognized as an insecticide, with formicidal action on $A$. sexdens rubropilosa (Sumida et al., 2010). However, in the present study, when the workers were subjected to contact with its individualized components, salicylic acid was more impactful, causing $100 \%$ cumulative mortality after $24 \mathrm{~h}$.

Boric acid-based baits have been studied for the control of Anoplolepis tenella Santschi ants, in the cassava crop, with promising results (Hanna, Kuate, Nanga, Tindo, \& Nagel, 2015). Although the mechanism of borate toxicity has not been fully elucidated, the acceptance of this active ingredient in bait varies according to the species studied. It is commonly used in the USA for the control of ants in urban areas (Sola, Falibene, \& Josens, 2013). Its action as an ant killer is known to be considered slow. The present findings corroborate these results, since the effect was more accentuated only three days after application, and it is important to stress that it was topical and not oral.

C. A. P. T. also provided $90 \%$ mortality in $A$. crassispinus after $48 \mathrm{~h}$. It should be noted that, by $24 \mathrm{~h}$, the application of SA had resulted in $100 \%$ cumulative mortality (Figure 2). No studies were found on the use of salicylic acid for the control of Acromyrmex ants with direct application on the insects. Some species of ants produce salicylic acid in their metapleural glands, aiming especially at defense against other organisms, such as Crematogaster sp. Lund, whose action against other arthropods is highlighted (Vander Meer, 2012). However, in the case of Atta sexdens and Acromyrmex, only other acids were determined in the metapleural gland, with an emphasis on indole acetic acid and hydroxyhexanoic acid (Vander Meer, 2012).

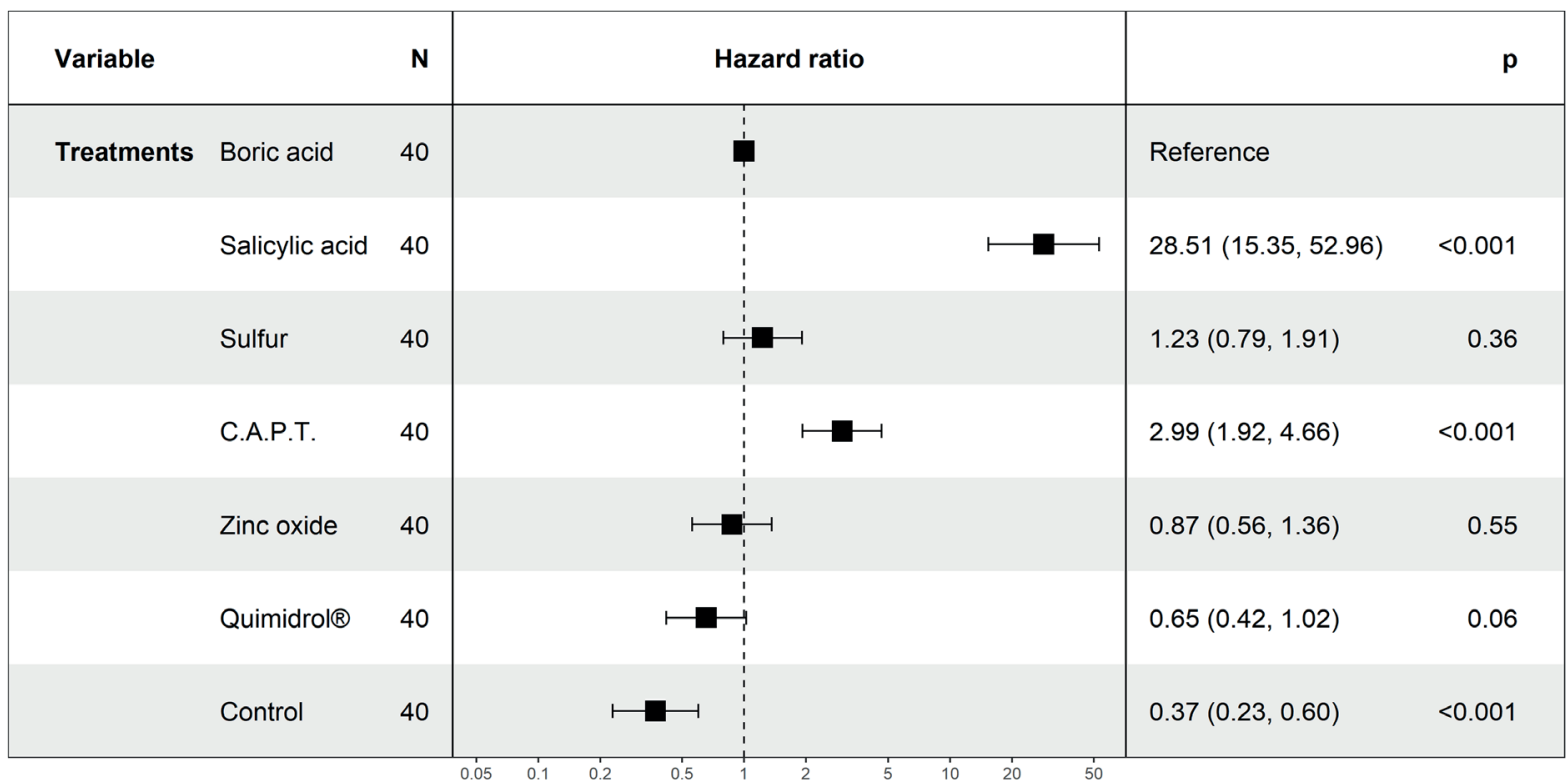

Figure 2. COX proportional-hazards model, with relative risk and confidence interval for mortality of Acromyrmex crassispinus workers subjected to dry-powder chemical treatments. Londrina-PR, Brazil, 2019. 
Recent studies have tested ascorbic acid, via diet, on the red imported fire ant Solenopsis invicta Buren (Ning et al., 2020), and yielded promising results, given the significant laboratory mortality, with prospects for use in ant baits.

In the present study, salicylic acid stood out for its insecticidal potential, because when applied directly to Atta sexdens rubropilosa and Acromyrmex crassispinus, it caused total mortality of the workers $24 \mathrm{~h}$ after its application. As such, it constitutes an alternative for the control of these insects, warranting field studies as well as providing control prospects and adding value to the Integrated Management of leaf-cutting ants.

Methyl salicylate is known to have fumigant action against adults of the beetle Callosobruchus chinensis (Coleoptera: Bruchidae) Linnaeus (Park, Shin, \& Kim, 2016), but not contact action. In the case of SA, there are no studies on its mode of action on ants or even other insects.

The fact that plants produce salicylic acid for protection against insects and diseases, as well as the strategy of some ants to also produce salicylic acid as a means of protecting themselves against other arthropods, support the laboratory results obtained here for both ant species.

Thanks are due to Dr. Adriano T. Hoshino for identifying the ant species and to Dr. Inês C. Batista Fonseca for helping with the statistical analyses.

\section{References}

Bhatla, S. C., \& Lal, M. A. (2018). Plantphysiology, development and metabolism. Singapore: Springer.
Brito, R. M. (2018). Desenvolvimento de iscas contendo fungos entomopatogênicos para o controle da saúva limão (Atta sexdens). Tese de doutorado, Universidade Estadual de Londrina, Londrina, PR, Brasil. Recuperado de http:// www.bibliotecadigital.uel.br

Della Lucia, T. M. C., Gandra, L. C., \& Guedes, R. N. C. (2014). Managing leaf-cutting ants: peculiarities; trends and challenges. Pest Management Science, 70(1), 14-23. doi: 10.1002/ps.3660

Gao, Q. M., Zhu, S., Kachroo, P., \& Kachroo, A. (2015). Signal regulators of systemic acquired resistance. Frontiers in Plant Science, 6, 228. doi: 10.3389/fpls.2015. 00228

Hanna, R., Kuate, A. F., Nanga, S. N., Tindo, M., \& Nagel, P. (2015). Boric acid for suppression of the ant Anoplolepis tenella and effects on an associated scale insect pest Stictococcus vayssierei in cassava fields in the Congo Basin. Crop Protection, 74(1), 131-137. doi: 10.1016/j. cropro.2015.04.016

Jameel, M., Shoeb, M., Khan, M. T., Ullah, R., Mobin, M., Farooqi, M. K., \& Adnan, S. M. (2020). Enhanced insecticidal activity of thiamethoxam byzinc oxide nanoparticles: a novel nanotechnology approach for pest control. ACS Omega, 5(3), 16071615. doi: 10.1021/acsomega.9b03680

Ning, D., Hassan, B., Nie, L., Yang, K., Pan, Y., Pan, Z., \& Xu, Y. (2020). I-ascorbic acid provides a highly effective and environmentally sustainable method to control red imported fire ants. Journal of Pest Science, 93(2), 879-891. doi: 10.1007/s10340-020-01203-z 
Park, C. G., Shin, E., \& Kim, J. (2016). Insecticidal activities of essential oils, Gaultheria fragrantissima and Illicium verum, their components and analogs against Callosobruchus chinensis adults. Journal of Asia-Pacific Entomology, 19(2), 269273. doi: 10.1016/j.aspen.2016.03.001

Rheinheimer, A. R., Angell, A. L. F., Pietrowski, V., Bellon, P. P., Monsani, M. A., \& Gazola, D. (2012). Produtos fitossanitários alternativos no controle da moscabranca (Bemisia tuberculata) (MatileFerrero), na mandioca. Semina: Ciências Agrárias, 33(4), 14-19. doi: 10. 5433/1679.2012v33n4p1419

Sola, F., Falibene, A., \& Josens, R. (2013). A resposta comportamental assimétrica a dois tóxicos do boro depende das espécies de formigas (Hymenoptera: Formicidae). Jornal de Entomologia Econômica, 106(2), 929-938. doi: 10.16 03/EC12246
Sumida, S., Silva-Zacarin, E. C. da, Decio, P., Malaspina, O., Bueno, F. C., \& Bueno, O. C. (2010). Toxicological and histopathological effects of boric acid on Atta sexdens rubropilosa (Hymenoptera: Formicidae) workers. Journal of Economic Entomology, 103(3), 676-690. doi: 10.1603/EC09159

Swanson, A. C., Schwendenmann, L., Allen, M. F., Aronson, E. L., Artavia-León, A., Dierick, D.,... Zelikova, T. J. (2019). Welcome to the Atta world: A framework for understanding the effects of leaf cutter ants on ecosystem functions. Functional Ecology, 33(8), 1386-1399. doi: 10.1111/1365-24 35.13319

Vander Meer, R. (2012). Ant interactions with soil organisms and associated semiochemicals. Journal of Chemical Ecology, 38(6), 728-745. doi: 10.1007/s10 886-012-0140-8 